\title{
EFFECT OF FLOCCULATION IN MEMBRANE-FLOCCULATION HYBRID SYSTEM IN WATER REUSE
}

\author{
H. K. Shon ${ }^{1}$, W. S. Guo ${ }^{1}$, S. Vigneswaran ${ }^{*}$, H. H. Ngo ${ }^{1}$ and In S. Kim ${ }^{2}$ \\ ${ }^{1}$ Faculty of Engineering, University of Technology, Sydney, \\ P.O. Box 123, Broadway, NSW 2007, Australia \\ ${ }^{2}$ Water Reuse Technology Center, Kwangju Institute of Science and Technology, \\ Gwangju, Korea \\ * The author to whom all the correspondence should be addressed. \\ Email: s.vigneswaran $($ uts.edu.au
}

\begin{abstract}
Pre-flocculation reduces the fouling of membranes in cross-flow microfiltration thus leading to high quality product water at economic filtration flux. As such, this hybrid system will have a major impact in treating the biologically treated sewage effluent. The preflocculation achieved through the floating medium flocculation (FMF) was found to increase the phosphorus removal up to $96 \%$. The decline in microfiltration permeate flux with time was reduced by the incorporation of flocculation. However, the improvement in the removal of dissolved organic carbon (DOC) was marginal (from $20 \%$ with membrane
\end{abstract}


alone to $46 \%$ with membrane-flocculation hybrid system). The flocculation followed by adsorption as pretreatment helped to increase the DOC removal as high as $98 \%$.

Flocculation was found to remove more than $66 \%$ of colloidal effluent organic matter (EfOM). An attempt was also made to quantify the hydrophobic fraction in the pretreated effluent and to identify the molecular weight range of organics removed by the flocculation. The pre-treatment of flocculation was found to remove $62.9 \%, 68.5 \%$, and $51.6 \%$ of hydrophobic, hydrophilic, and transphilic organic matter. The molecular weight size distribution analysis indicated that flocculation with ferric chloride removed a majority of organic matter in the molecular weight range of $300-5,000$ daltons.

Keywords: Cross-flow microfiltration, flocculation, floating medium flocculation, hydrophobicity, molecular weight size distribution, biologically treated sewage effluent, effluent organic matter

\section{INTRODUCTION}

Wastewater reuse is being increasingly emphasized as a strategy for rational use of limited resources of freshwater and as a means of safeguarding the deteriorating aquatic environment due to wastewater disposal. Reuse of wastewater has become all the more important in small and isolated communities where alternative sources of freshwater are neither available nor cost-effective. Conventional sewage treatment includes primary 
treatment to remove the majority of suspended solids, secondary biological treatment to remove the biodegradable dissolved organics and nitrogen, and tertiary treatment to remove most of the remaining organic solids and pathogenic microorganisms. Although the effluent from the secondary and tertiary wastewater treatment can be discharged into waterways, it can not be used for many non-potable reuse purposes without further treatment. To obtain water of recyclable quality, membrane processes are being used. Although reverse osmosis and nano-filtration can remove the majority of the pollutants including the dissolved organics, their operational cost is high due to high energy requirement and membrane fouling. Microfiltration is cost-effective option but it cannot remove dissolved organic matter due to its relatively larger pore sizes.

Flocculation as pretreatment can remove some of the organic colloids present in the biologically treated sewage effluent. It also helps in reducing the membrane fouling. AlMalack and Anderson (1) and Chapman et al. (2) have studied the effect of flocculation on the performance of cross-flow microfiltraion of domestic wastewater and biologically treated effluent respectively. Abdessemed et al., (3) showed experimentally that the flocculation-adsorption process removed $86 \%$ of chemical oxygen demand from domestic wastewater. Their study used $\mathrm{FeCl}_{3}$ at a concentration of $40 \mathrm{mg} / \mathrm{L}$ and powdered activated carbon at a dose of $20 \mathrm{mg} / \mathrm{L}$.

The coupling of flocculation and microfiltration has been studied by Peuchot and Ben Aim (4). They used a synthetic suspension made of predetermined concentration of bentonite. Polyaluminium chloride was used as flocculant. Their results show that the coupling 
significantly improved the membrane flux and gave rise to excellent filtrate quality. Vigneswaran and Boonthanon (5) also showed that the crosssflow microfiltration with inline flocculation reduces the clogging of membranes thus leading to water productivity of high quality at an economical filtration flux (rate). In their study, the filtration flux could be increased by more than $200 \%$ by adopting in-line flocculation. The filter backwash wastewater from a water treatment plant in Bangkok, Thailand was used in their study.

Another study with biologically treated sewage effluent also showed a flux improvement by preflocculation (2). In this study, floating medium flocculator (FMF) with an in-line flocculant addition was used. The buoyant medium flocculator used in this study worked as a static flocculator and filter. The concept of using buoyant medium (materials less dense than water) for flocculation and filtration in water and wastewater treatment has been the focus of several studies over the last decade $(7,8,9,10)$. A new high-rate flocculationfiltration system was used by Vigneswaran et al. (11) in water and wastewater treatment applications.

In the present research, the effect of pretreatment of flocculation was investigated in terms of enhancement of total organic carbon (TOC) removal and reduction in the filtration flux decline of microfiltration (or the reduction of membrane fouling with time). This study was conducted in two parts with biologically treated sewage effluent. In the first part, a high rate static flocculator (floating medium flocculator) was used; in the second part, the effluent with and without pretreatment was characterized in terms of colloidal matter, hydrophobic fraction, and molecular weight range. 


\section{MATERIALS AND METHODS}

\subsection{Treatment methods}

The study was carried out with biologically treated sewage effluent drawn from the sewage treatment wastewater plant (Table 1). The effect of $\mathrm{FeCl}_{3}$ flocculation and powered activated carbon (PAC) adsorption in removing effluent organic matter (EfOM) was investigated. The removal of EfOM was studied in terms of total organic carbon (TOC). The amounts of EfOM colloidal matter and hydrophilic and hydrophobic organic fractions were experimentally determined. The molecular weight (MW) sizes removed by different pretreatments were also analyzed.

\subsubsection{Flocculation}

Flocculation was carried out with ferric chloride $\left(\mathrm{FeCl}_{3}\right)$ of predetermined doses. It was selected as a coagulant because it is more effective than alum in removing TOC (12). Further, ferric chloride can also remove small MW organic matter through complexation mechanism. The biologically treated sewage effluent was placed in six 1 L containers, where known amounts of ferric chloride were added. The dose of $\mathrm{FeCl}_{3}$ was added from $20 \mathrm{mg} / \mathrm{L}$ to $200 \mathrm{mg} / \mathrm{L}$. The samples were then stirred rapidly for 1 minute at $100 \mathrm{rpm}$, followed by 20 minutes of slow mixing at $30 \mathrm{rpm}$, and 30 minutes of settling. The supernatant was taken and analyzed for TOC to determine the optimum $\mathrm{FeCl}_{3}$ dose. The molecular weight distribution of the organic matter was also measured. Here, the 
optimum dose of $\mathrm{FeCl}_{3}$ dose was chosen to achieve superior TOC and phosphorus removal.

\subsubsection{PAC adsorption}

Adsorption with PAC was conducted using $1 \mathrm{~L}$ of biologically treated sewage effluent. The PAC used in the experiments was washed with distilled water and dried in the oven at $103.5^{\circ} \mathrm{C}$ for 24 hours. It was then kept in a desiccator before using in the adsorption experiments. One g/L PAC was stirred with mechanical stirrer at $100 \mathrm{rpm}$ for 1 hour. The ambient temperature was maintained at $25{ }^{\circ} \mathrm{C}$. Few experiments with a pretreatment of flocculation followed by PAC adsorption of the supernatant were also conducted.

\subsubsection{Experimental set-up (of the FMF hybrid system)}

The floating medium flocculation (FMF) column was packed with polystyrene beads (diameter of $1.9 \mathrm{~mm}$, density of $50 \mathrm{~kg} / \mathrm{m}^{3}$, and depth of $1000 \mathrm{~mm}$ ) (Figure 1). This FMF unit was operated at a high filtration velocity of $30 \mathrm{~m} / \mathrm{h}$ and a dose of $\mathrm{FeCl}_{3}(50 \mathrm{mg} / \mathrm{L})$ was provided to achieve phosphorus precipitation in addition to the flocculation of suspended solids. A periodic backwash for 1 minute after every different operational time was made to clean the floating medium. The backwash flow rate was $30 \mathrm{~m} / \mathrm{h}$. The effluent from the flocculator was used as feed water to the crossflow microfiltration (CMF) unit. The CMF membrane used in the on-site experiments was a hollow fiber membrane filter unit. The membrane material is polypropylene with a pore size of $0.2 \mu \mathrm{m}$ 
and a total membrane area of $1 \mathrm{~m}^{2}$. The CMF unit is equipped with an air backwash system, in which compressed air is used to dislodge waste particles from the surface of the membrane as part of the backwash sequence. This is followed by a series of high power water blasts to wash the particles out of the membrane system into backwash water. The crossflow microfiltration (CMF) was operated at a transmembrane pressure (TMP) range of $10-20 \mathrm{kPa}$ and a backwash air pressure of $900-1000 \mathrm{kPa}$. The benefits of pretreatment of flocculation were measured in terms of total organic carbon (TOC) and orthophosphate removal and reduction in membrane fouling.

\subsection{EfOM characterization}

\subsubsection{Colloidal organic fraction}

The dialysis was performed with Spectra/Por-3 regenerated cellulose dialysis membrane bag (molecular weight cut off (MWCO) 3,500 daltons). The dialysis membrane was washed by soaking it in $4 \mathrm{~L}$ of pure water for 24 hours. The wastewater sample was acidified with $\mathrm{HCl}$ to $\mathrm{pH} 1$ and placed in the pre-washed dialysis membrane bag. It was dialyzed for 8 hours (each time) against three $4 \mathrm{~L}$ portions of $0.1 \mathrm{~N} \mathrm{HCl}$ (to remove salts and low MW of EfOM). It was then dialyzed until the silica gel precipitate is dissolved against $4 \mathrm{~L}$ of $0.2 \mathrm{~N} \mathrm{HF}$. Finally, it was dialyzed for 12 hours (each time) against two $4 \mathrm{~L}$ portions of pure water. This is to remove residual HF and flurosilicic acid. Finally, the sample was taken out the dialysis membrane from the last $4 \mathrm{~L}$ of dialysate of deionized 
water and measured for its TOC content. This represents the EfOM colloidal matter (with molecular weight range from 3,500 daltons to $0.45 \mu \mathrm{m})(13)$.

\subsubsection{XAD fractionation of EfOM}

XAD-8 and XAD-4 resins were used for fractionating EfOM into hydrophobic EfOM (XAD-8 adsorbable; mostly hydrophobic acids with some hydrophobic neutrals), transphilic EfOM (XAD-4 adsorbable; hydrophilic bases and neutrals) components. The remaining fraction escaping the XAD-4 was the hydrophilic component.

\subsubsection{Molecular weight (MW) distribution}

The wastewater effluent after each pretreatment was subjected to MW distribution measurements. High performance size exclusion chromatography (HPSEC, Shimadzu Corp., Japan) with a SEC column (Protein-pak 125, Waters, Milford, USA) was used to determine the MW distributions of organics. Standards of MW of various polystyrene sulfonates (PSS: 210, 1800, 4600, 8000, and 18000 daltons) were used to calibrate the equipment. Details on the measurement methodology are given elsewhere (13). 


\section{RESULTS and DISCUSSION}

\subsection{Experimental results on the hybrid system}

The performance of floating medium flocculation (FMF) was first studied at a high velocity $(30 \mathrm{~m} / \mathrm{h})$ and at a backwash frequency of 1 minute after every 45, 60, and 90 minute operation. The biologically treated sewage effluent from a sewage treatment plant was used in this study. The headloss profile is shown in Figure 2 for different filter backwash frequencies. For all cases, the headloss development was not too high, and returned to the clean bed headloss value soon after the backwash. This periodic backwash with short duration of 1 minute, reduced the backwash water requirement (less than 1 $2 \%$ of the water production). The floc size in the flocculator effluent was uniform in the range of $20-30 \mu \mathrm{m}$.

The performance of crossflow microfiltration (CMF) with and without FMF as pretreatment was studied. The results indicate that the membrane has the ability to remove most of the suspended solids without any pretreatment (Table 2). However, the membrane's ability in reducing phosphorus and TOC was limited without any pretreatment (only $5 \%$ of orthophosphate and less than $20 \%$ of TOC removal). When the pretreatment of flocculation (floating medium flocculator) was used, the removal of orthophosphate increased to $96 \%$. The TOC removal increased to $46 \%$. This suggests that flocculation alone as pretreatment is not adequate in removing the dissolved organics although it is helpful in achieving of the phosphorus removal. The flocculation followed 
by the adsorption with powdered activated carbon (PAC) was found to increase the TOC removal to more than 99\% (Table 2). With the pretreatment of flocculation, the decline in membrane filtration flux with time was lower (Figure 3).

Figure 3 presents filtration flux profile. When the wastewater was not pre-flocculated, the filtration flux was found to decline from $216 \mathrm{~L} / \mathrm{m}^{2} \mathrm{~h}$ to $180 \mathrm{~L} / \mathrm{m}^{2} \mathrm{~h}$ in six hours. The adoption of flocculation slowed down the declining rate of the filtration flux. During the six-hour experiment, the filtration flux only decreased from $216 \mathrm{~L} / \mathrm{m}^{2} \mathrm{~h}$ to $205 \mathrm{~L} / \mathrm{m}^{2} \mathrm{~h}$ with flocculation as pretreatment.

\subsection{The nature of organics removed by flocculation}

Although flocculation is found to improve suspended solids, phosphorus and TOC removal, one does not know the nature and the molecular weight (MW) size range of the organics removed by this process. Information on these parameters will be useful in optimizing the flocculation conditions and to supplement it with the other pretreatment processes to remove the pollutants that were not removed by the flocculation. For example, when an additional pretreatment of powdered activated carbon (PAC) adsorption was used following flocculation, the TOC removal efficiency increased significantly (>99\% TOC removal).

Hence, the second part of the experiments concentrated on studying the quantity of hydrophobic, hydrophilic, and transphilic fractions of organic matter removed by the pretreatment of flocculation. In this part of the experimental study, secondary treated 
sewage effluent with higher TOC was used to get more accurate values on the fractions. The colloidal and non-colloidal fractions removed by flocculation were experimentally determined. The MW ranges that were removed by flocculation with different doses of $\mathrm{FeCl}_{3}$ were also investigated.

\subsubsection{Determination of optimum flocculant dose}

First of all, batch flocculation experiments were conducted with jar test with different doses of ferric chloride. Different doses of $\mathrm{FeCl}_{3}$, (ranging between $10 \mathrm{mg} / \mathrm{L}$ and 200 $\mathrm{mg} / \mathrm{L}$ ) were added to $1 \mathrm{~L}$ of secondary sewage effluent (Table 3). The optimum dose of $120 \mathrm{mg} / \mathrm{L}$ was chosen to achieve not only the solid removal but also superior, phosphorus, and TOC removal.

\subsubsection{Determination of EfOM colloidal fraction}

The colloidal fractions were investigated with regenerated cellulose dialysis membrane bag. The TOC concentration of colloids in the biologically treated sewage effluent was $4.04 \mathrm{mg} / \mathrm{L}$, whereas the TOC concentration of colloids after flocculation was $1.4 \mathrm{mg} / \mathrm{L}$. Thus, the removal of colloids after $\mathrm{FeCl}_{3}$ pretreatment was $66.3 \%$. It should be noted that the colloidal portion is the one having a size between 3,500 daltons and $0.45 \mu \mathrm{m}$.

\subsubsection{Determination of hydrophobic/hydrophilic organic fraction}


These fractions were experimentally measured for effluents with and without flocculation. The mass fractions of hydrophobic, hydrophilic, and transphilic components removed by flocculation were $62.9 \%, 51.6 \%$, and $68.5 \%$, respectively (Table 4). The removal of hydrophilic organics by flocculation may be due to the addition of very high dose of $\mathrm{FeCl}_{3}$ (which may have led to sweep flocculation).

\subsubsection{Determination of molecular weight fraction}

The MW of the EfOM in biologically treated effluent ranged from 300 daltons to about 400,000. The highest MW fraction was $300-5000$ daltons. The MW distribution was analyzed by high performance size exclusion chromatography (HPSEC) with elapsed time. The absorbance versus elapsed time plot was constructed for both flocculated and non-flocculated samples (Figure 4). According to Figure 4, the points of inflection for the wastewater studied were found at the molecular weight of 98943, 53561, 4729, and 373 daltons, which are denoted by A, B, C, and D. The figure also shows the HPSEC response for different MW compounds. The removal mechanism of small MW organic matter by flocculation with $\mathrm{FeCl}_{3}$ is mainly due to complexation of $\mathrm{Fe}$ at wide range of $\mathrm{pH}(5.5-7.5)(14)$. In this present experiment, the $\mathrm{pH}$ was in between $6.7-7.3$. The adsorption of small organic molecules onto Fe hydroxide also occurred at a neutral $\mathrm{pH}$ (15). 


\section{CONCLUSIONS}

The flocculation as pretreatment to crossflow microfiltration (CMF) was successful in removing phosphorus. Although there was an increase in effluent organic matter (EfOM) removal by flocculation, it was not significantly high ( $46 \%$ TOC removal). The flocculation followed by adsorption as pretreatment helped to increase the DOC removal as high as $98 \%$. The preflocculation also helped to reduce the decline in the microfiltration flux, which is due to organic colloidal removal from wastewater effluent by flocculation. The floating medium flocculation used in this study to provide the flocculation was found to be a compact process due to its operation at very high through put rates $(30 \mathrm{~m} / \mathrm{h})$ with relatively less amount of backwash water (less than $1.5 \%$ of water production). The use of buoyant medium in the static flocculation reduces the energy requirement for backwash (2).

A detailed organic characterization indicated that the flocculation can remove more than $65 \%$ of colloidal organic matter with size greater than 3,500 daltons. The hydrophobic and hydrophilic organic matters removed by flocculation were $62.9 \%$ and $51.6 \%$, respectively. The removal of hydrophilic organic matter may be due to the large dose of $\mathrm{FeCl}_{3}$ added. The flocculation also removed a significant amount of small molecular weight organic matter. This is mainly due to complexation of Fe. The adsorption of organic molecules onto $\mathrm{Fe}$ hydroxide was also responsible for small molecular weight organic matter removal. 


\section{ACKNOWLEDGEMENTS}

This research was funded by Australian Research Council (ARC) discovery grant. The support of Brain Pool Korea for the visit of S. Vigneswaran during the period of March June, 2003 is greatly appreciated.

\section{REFERENCES}

(1) Al-Malack, M.H.; Anderson, G.K. Coagulation-crossflow microfiltration of domestic wastewater. J. Membrane Sci. 1996, 121 (1), 59-70.

(2) Chapman, H.; Vigneswaran, S.; Ngo, H. H.; Dyer, S.; Ben Aim, R. Preflocculation of secondary treated wastewater in enhancing the performance of microfiltration. Desal. 2002, 146, 367-372.

(3) Abdessemed, D.; Nezzal, G.; Ben Aim, R. Coagulation-adsorption-ultrafiltration for wastewater treatmentand reuse. Desal. 2000 131, 307-314.

(4) Peuchot, M.; Ben Aim, R. In: Couplage de la floculation et de la microfiltration tangentielle, Récents progrès en Génie des Procédés 8a. Lavoisier, Toulouse, 1989, 313319.

(5) Vigneswaran, S.; Boonthanon, S. Cross flow microfiltration with in line flocculation. Water, 1992, 29-31. 
(6) Levine, A. D.; Tchobanoglous, G.; Asano, T. Characterization of the size distribution of contaminants in wastewater: treatment and reuse implications. J. WPCF, 1985, 57:7, 805-816.

(7) Ben Aim, R.; Shanoun, A.; Visvanathan, C.; Vigneswaran, S. New Filtration Media and their Use in Water Treatment, Proceedings, World Filtration Congress, Nagoya, Japan, 1993, 273-276.

(8) Sugaya, K. Filtration of Sewage Treated Water by the Use of Floating Media Proceedings. World Filtration Congress, Nagoya, Japan, 1993, 729-733.

(9) Schulz, C. R.; Singer, P. C.; Gandley, R.; Nix J. E. Evaluating buoyant coarse media flocculation. J. Am. Wat. Wks Ass., 1994, 86, 51-62.

(10) Ngo, H. H.; Vigneswaran, S. Application of floating medium filter in water and wastewater treatment with contact-flocculation filtration arrangement. J. Water ResearchIAWQ, 1995, 29 (9), 2211-2213.

(11) Vigneswaran, S.; Ngo, H. H.; Kwon, D. Y.; Hu, J. Y. A new high rate filtration system in water recycle. Civil and Environmental Engineering Conference, New Frontiers \& Challenges, Bangkok, 1999, 1, 1-7.

(12) Kawamura, S. Integrated design and operation of water treatment facilities. John Wiley \& Sons, Inc, $2^{\text {nd }}$ ed., New York, 2000, 89-93.

(13) Her, N. G., Identification and characterization of foulants and scalants on NF membrane. Doctoral thesis of philosophy, University of Colorado, 2002, 40 -49.

(14) Vilge-Ritter, A.; Rose, J.; Masion, A.; Bottero, J. Y.; Laine, J. M. Chemistry and structure of aggregates formed with Fe-salts and natural organic matter. Colloids and Surfaces, 1999, 297-308. 
(15) Dempsey, B.A.; Ganho, R.N.; O’Melia, C.R. Coagulation of humic substances by means of aluminum salts. J. Am. Wat. Wks Ass., 1984, 74, 141-150.

Table 1 Characteristics of biologically treated sewage effluent from wastewater treatment plant

Table 2 Effluent quality with different pretreatments. $\left(\mathrm{FMF}\right.$ velocity $=40 \mathrm{~m} / \mathrm{h} ; \mathrm{FeCl}_{3}=$ $50 \mathrm{mg} / \mathrm{L} ;$ PAC dose = $1 \mathrm{~g} / \mathrm{L} ;$ PAC mixing time 1-2 minutes; Influent TOC Average = $2.75 \mathrm{mg} / \mathrm{L}$; experimental duration $=2$ hours)

Table 3 TOC removal efficiency at different doses of $\mathrm{FeCl}_{3}$ (with secondary effluent of TOC mg/L of $10.01 \mathrm{mg} / \mathrm{L})$

Table 4 Hydrophobic, transphilic, and hydrophilic fractions of biologically treated sewage effluent before and after flocculation with $120 \mathrm{mg} / \mathrm{L}$ of $\mathrm{FeCl}_{3}$ 
Table 1 Characteristics of biologically treated sewage effluent from wastewater treatment plant

\begin{tabular}{ccccccc}
\hline TOC & $\mathrm{BOD}_{5}$ & & $\mathrm{SS}$ & $\mathrm{TN}$ & $\mathrm{TP}$ & Conductivity \\
$(\mathrm{mg} / \mathrm{L})$ & $(\mathrm{mg} / \mathrm{L})$ & & $(\mathrm{mg} / \mathrm{L})$ & $(\mathrm{mg} / \mathrm{L})$ & $(\mathrm{mg} / \mathrm{L})$ & $(\mu \mathrm{S} / \mathrm{cm})$ \\
\hline $3.16-10.4$ & $9.1-19$ & $6.8-7.5$ & $3.5-5.0$ & $23.2-40$ & $6.0-10.0$ & $200-584$ \\
\hline
\end{tabular}


Table 2 Effluent quality with different pretreatments. $\left(\mathrm{FMF}\right.$ velocity $=40 \mathrm{~m} / \mathrm{h} ; \mathrm{FeCl}_{3}=$ $50 \mathrm{mg} / \mathrm{L} ;$ PAC dose $=1 \mathrm{~g} / \mathrm{L} ;$ PAC mixing time $1-2$ minutes; Influent TOC Average $=$ $2.75 \mathrm{mg} / \mathrm{L}$; experimental duration $=2$ hours $)$

\begin{tabular}{|c|c|c|c|c|c|c|c|}
\hline & $\begin{array}{c}\text { Quality of } \\
\text { biologically } \\
\text { treated } \\
\text { effluent }\end{array}$ & $\begin{array}{c}\text { Membrane } \\
\text { without } \\
\text { pretreatment }\end{array}$ & $\begin{array}{c}\text { Removal } \\
\text { efficiency } \\
(\%)\end{array}$ & $\begin{array}{l}\text { Flocculation } \\
+ \text { Membrane }\end{array}$ & $\begin{array}{l}\text { Removal } \\
\text { efficiency } \\
(\%)\end{array}$ & $\begin{array}{l}\text { Flocculation } \\
+ \text { adsorption } \\
+ \text { membrane }\end{array}$ & $\begin{array}{c}\text { Removal } \\
\text { efficiency } \\
(\%)\end{array}$ \\
\hline $\begin{array}{c}\text { TOC } \\
(\mathrm{mg} / \mathrm{L})\end{array}$ & 3.16 & 2.53 & 20 & 1.71 & 46 & 0.074 & 98 \\
\hline $\begin{array}{c}\mathrm{PO}_{4}^{-3} \\
(\mathrm{mg} / \mathrm{L})\end{array}$ & 6.63 & 6.3 & 5 & 0.24 & 96 & 0.2 & 97 \\
\hline $\begin{array}{c}\text { Turbidity } \\
\text { (NTU) }\end{array}$ & 8 & $<0.1$ & $>99 \%$ & $<0.1$ & $>99 \%$ & $<0.1$ & $>99 \%$ \\
\hline
\end{tabular}


Table 3 TOC removal efficiency at different doses of $\mathrm{FeCl}_{3}$ (with secondary effluent of TOC mg/L of $10.01 \mathrm{mg} / \mathrm{L}$ )

\begin{tabular}{|c|c|c|}
\hline \multirow{2}{*}{$\mathrm{FeCl}_{3}$ dose $(\mathrm{mg} / \mathrm{L})$} & \multicolumn{2}{|c|}{ TOC } \\
\cline { 2 - 3 } & Value $(\mathrm{mg} / \mathrm{L})$ & \% reduction \\
\hline 10 & 9.0 & 10.1 \\
\hline 20 & 8.3 & 16.6 \\
\hline 40 & 7.5 & 24.6 \\
\hline 60 & 6.8 & 31.7 \\
\hline 80 & 5.9 & 40.7 \\
\hline 100 & 5.1 & 50.5 \\
\hline 120 & 4.7 & 53.9 \\
\hline 140 & 5.5 & 46.6 \\
\hline 160 & 6.0 & 41.2 \\
\hline
\end{tabular}


Table 4 Hydrophobic, transphilic, and hydrophilic fractions of biologically treated sewage effluent before and after flocculation with $120 \mathrm{mg} / \mathrm{L}$ of $\mathrm{FeCl}_{3}$

\begin{tabular}{|c|c|c|c|}
\hline Fraction & $\begin{array}{c}\text { Biologically treated sewage } \\
\text { effluent (TOC, mg/L) }\end{array}$ & $\begin{array}{c}\text { After flocculation } \\
\text { (TOC, mg/L) }\end{array}$ & \% reduction \\
\hline Hydrophobic & 4.98 & 1.85 & 62.9 \\
\hline Transphilic & 1.68 & 0.53 & 68.5 \\
\hline Hydrophilic & 3.29 & 1.22 & 51.6 \\
\hline
\end{tabular}


Figure 1 Schematic of adsorption-flocculation-microfiltration hybrid system

Figure 2 Performance of the floating medium flocculator (flocculator velocity $=30 \mathrm{~m} / \mathrm{h}$, polystyrene medium diameter $=1.9 \mathrm{~mm}$, filter depth $=0.8 \mathrm{~m}$, density $=0.05 \mathrm{~g} / \mathrm{cm}^{3}$; flocculator back wash duration $=1 \mathrm{~min}$; back wash velocity $=30 \mathrm{~m} / \mathrm{h}$ )

Figure 3 Filtration flux of CFMF versus filtration time (microfiltration flux $=220 \mathrm{~L} / \mathrm{m}^{2} \mathrm{~h}$; membrane backwash frequency $=36 \mathrm{~min}$; filtration velocity $=30 \mathrm{~m} / \mathrm{h} ; \mathrm{FeCl}_{3}=50 \mathrm{mg} / \mathrm{L}$; flocculator backwash frequency $=45 \mathrm{~min}$ )

Figure $4 \mathrm{MW}$ distributions of the secondary sewage effluent with and without flocculation. 


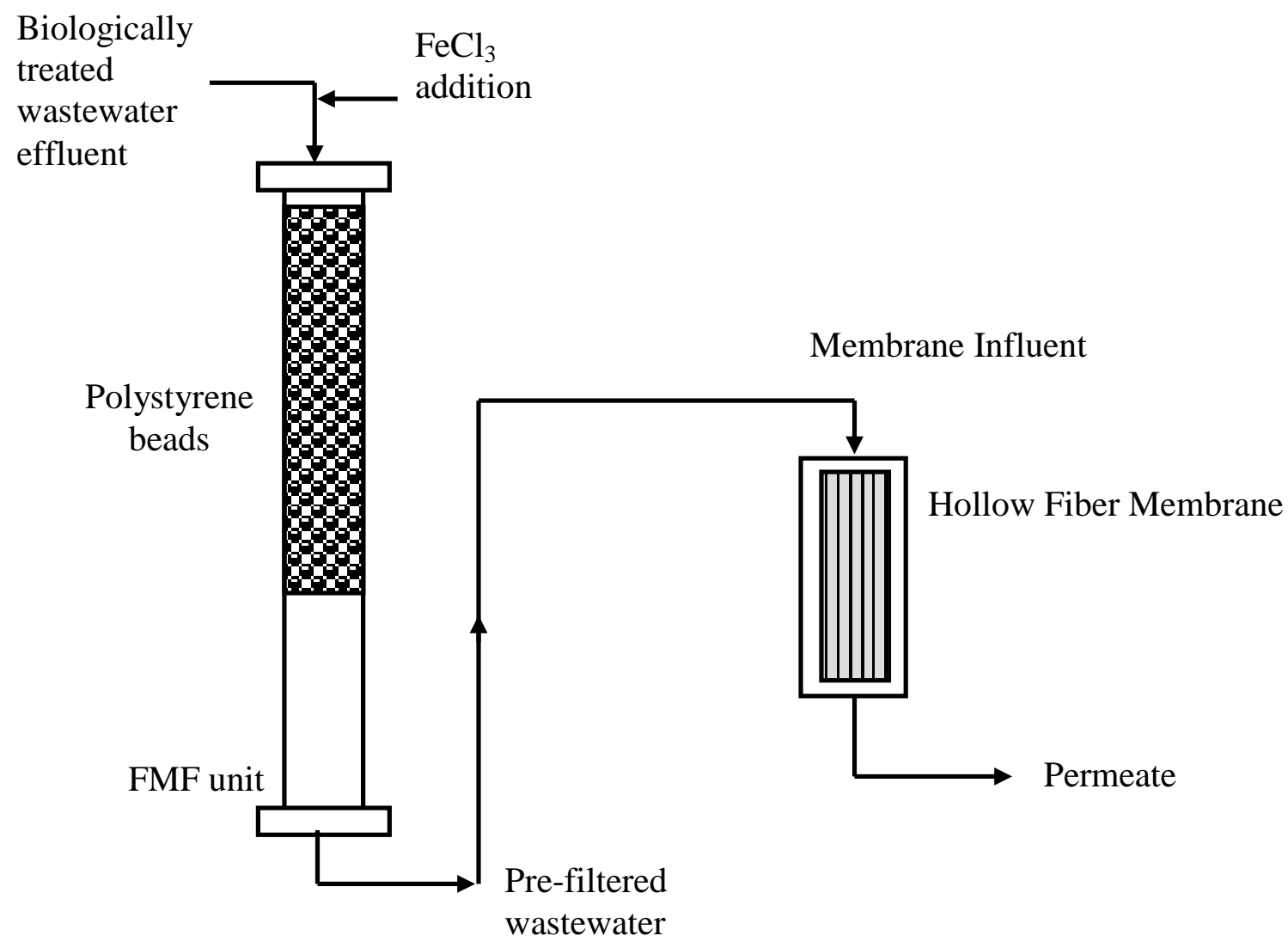

Figure 1 Schematic of flocculation-microfiltration hybrid system 


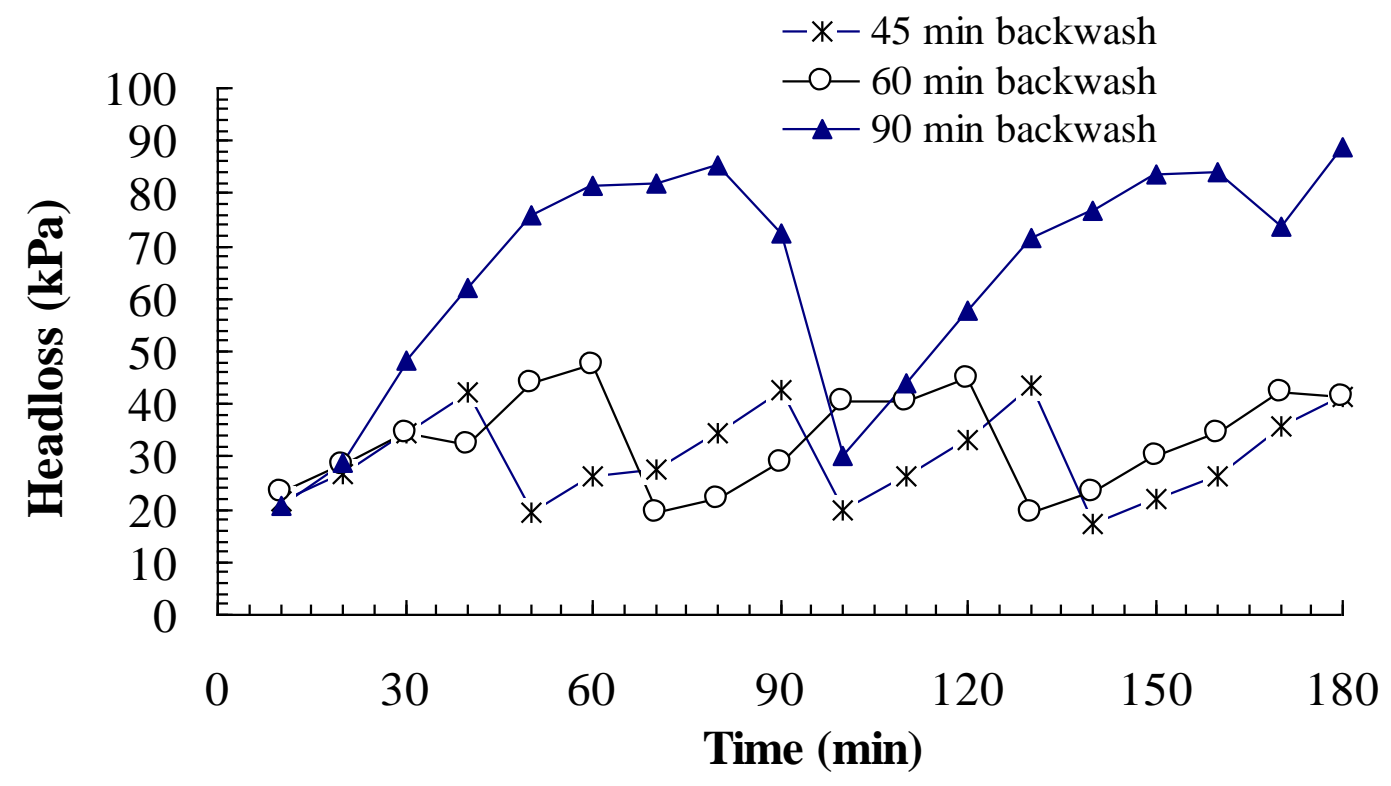

Figure 2 Performance of the floating medium flocculator (flocculator velocity $=30 \mathrm{~m} / \mathrm{h}$, polystyrene medium diameter $=1.9 \mathrm{~mm}$, filter depth $=0.8 \mathrm{~m}$, density $=0.05 \mathrm{~g} / \mathrm{cm}^{3}$; flocculator back wash duration $=1 \mathrm{~min}$; back wash velocity $=30 \mathrm{~m} / \mathrm{h}$ ) 


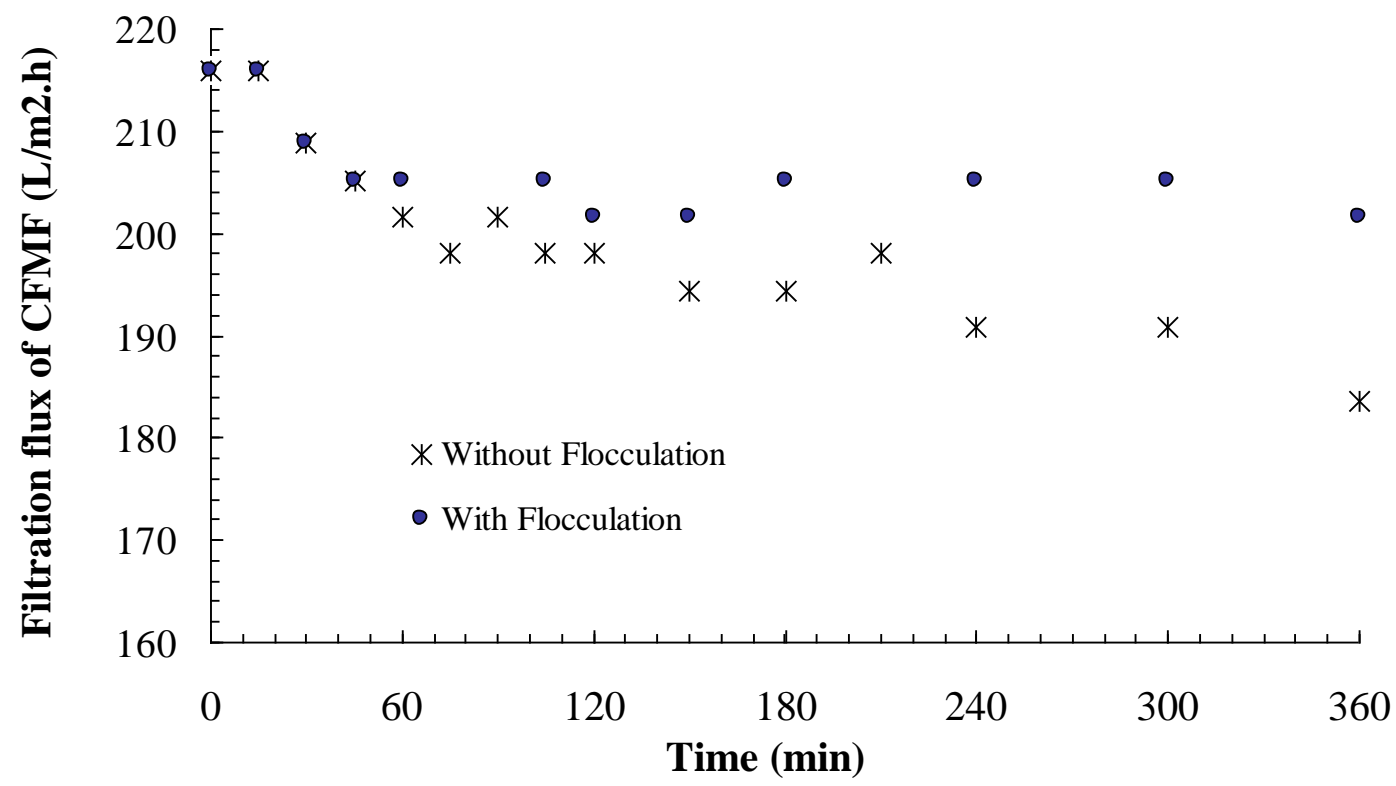

Figure 3 Filtration flux of CFMF versus filtration time (microfiltration flux $=220 \mathrm{~L} / \mathrm{m}^{2} . h$; membrane backwash frequency $=36 \mathrm{~min} ;$ filtration velocity $=30 \mathrm{~m} / \mathrm{h} ; \mathrm{FeCl}_{3}=50 \mathrm{mg} / \mathrm{L}$; flocculator backwash frequency $=45 \mathrm{~min}$ ) 


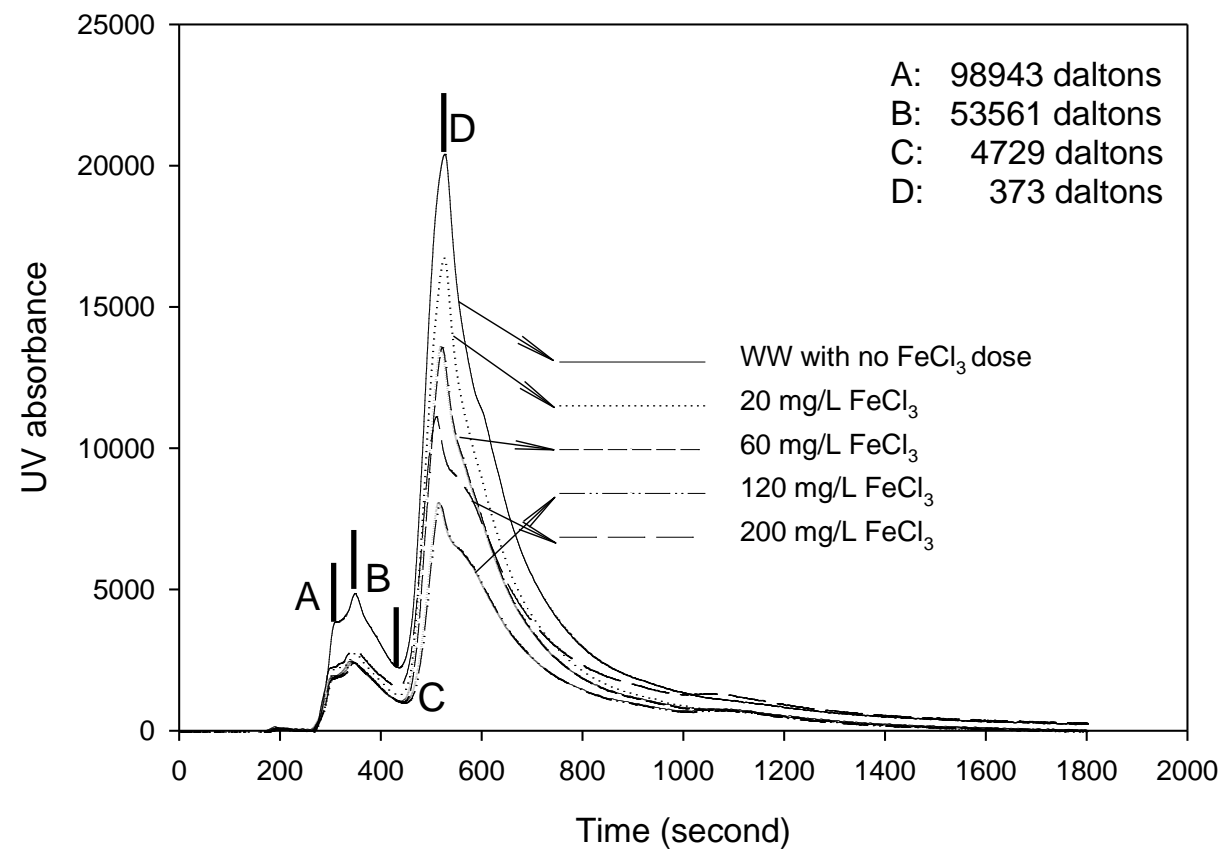

Figure 4 MW distributions of the secondary sewage effluent with and without flocculation. 